OPEN ACCESS

Edited by:

Mohammad U.H. Joardder, Rajshahi University of Engineering

Technology, Bangladesh

Reviewed by: Zakaria Tagnamas, Cadi Ayyad University, Morocco Mohammad Zarein Tarbiat Modares University, Iran

*Correspondence: Carlos Zambra czambra@utalca.cl

Roberto Lemus-Mondaca rlemus@uchile.c

Specialty section:

This article was submitted to Sustainable Food Processing, a section of the journal

Frontiers in Sustainable Food Systems

Received: 15 December 2020 Accepted: 19 February 2021 Published: 19 March 2021

Citation: Zambra C, Hernández D, Reyes $\mathrm{H}$, Riveros $N$ and Lemus-Mondaca $R$ (2021) Kageneckia oblonga Leaves Subjected to Different Drying Methods: Drying Kinetics, Energy Consumption and Interesting Compounds. Front. Sustain. Food Syst. 5:641858. doi: 10.3389/fsufs.2021.641858

\section{Kageneckia oblonga Leaves Subjected to Different Drying Methods: Drying Kinetics, Energy Consumption and Interesting Compounds}

\author{
Carlos Zambra ${ }^{1 *}$, Diógenes Hernández ${ }^{2}$, Hugo Reyes $^{1}$, Nicole Riveros ${ }^{1}$ and \\ Roberto Lemus-Mondaca ${ }^{3 *}$
}

${ }^{1}$ Departamento de Tecnologías Industriales, Universidad de Talca, Curicó, Chile, ${ }^{2}$ Departamento de Química, Universidad de Talca, Curicó, Chile, ${ }^{3}$ Departamento de Ciencia de los Alimentos y Tecnología Química, Facultad de Ciencias Químicas y Farmacéuticas, Universidad de Chile, Santiago, Chile

In this study, Kageneckia oblonga leaves were dried under different drying conditions and techniques [oven drying ( $\mathrm{NC}$ ), vacuum drying (VNC), convective drying ( $F C$ ), and microwave-assisted convective drying (MWFC)]. Thus, the effect of temperature, vacuum, and microwave on the drying features of $K$. oblonga leaves was determined. Fick's second law was used to calculate the effective moisture diffusivity that varied from 3.94 to $8.14 \times 10^{-11} \mathrm{~m}^{2} / \mathrm{s}, 1.12$ to $1.40 \times 10^{-11} \mathrm{~m}^{2} / \mathrm{s}, 7.83$ to $11.36 \times 10^{-11} \mathrm{~m}^{2} / \mathrm{s}$, and 6.93 to $16.72 \times 10^{-11} \mathrm{~m}^{2} / \mathrm{s}$ for NC, VNC, FC, and MWFC methods, respectively. In addition, the Weibull and Midilli-Kucuk models accurately predicted all experimental drying curves of $K$. oblonga leaves. Regarding the energy consumption and efficiency values for different drying methods of $K$. oblonga were found to be in the range of 0.20-7.50 kW.h and 0.10-3.70\%, respectively. The results showed that MWFC method does not significantly affect the phenolic compounds and could be used for large-scale production of $K$. oblonga dried leaves.

\footnotetext{
Keywords: Kageneckia oblonga, drying methods, moisture diffusivity, mathematical modeling, energy consumption, polyphenols
}

\section{INTRODUCTION}

Medicinal plants are a non-traditional export product that should be considered as part of a nation's agri-food supply. Kageneckia oblonga, also known as Bollén, is an endemic Chilean perennial tree, which resists conditions of extreme insolation and drought. In addition, it is characterized by having hard sawn leaves. K. oblonga is also found in north-facing slopes, exposed to full sun, with no conservation problems since it is one of the most common trees of the sclerophyll forests of central Chile (Rodríguez et al., 2006). It blooms from September to December and its fruit is a star-shaped capsule with five sections, from 2 to $3 \mathrm{~cm}$ diameter, containing numerous winged seeds (Russo and Garbarino, 2008). As for the traditional medicine, the infusion made from K. oblonga leaves is used to treat fever, liver, and kidney disorders (Montes and Wilkomirsky, 1985) due to its antipyretic, anti-inflammatory, and analgesic activity (Del Porte et al., 2002). These effects are related to the presence of ursolic acid in the leaves and branches of 
K. oblonga (Cassels and Ursúa, 1973), which has shown antiinflammatory effects (Recio et al., 1995). Other phytochemical investigations reported the isolation of a cyanogenic glycoside called prunasin, attributing part of the anti-inflammatory effect to it (Fikenscher et al., 1981). For its conservation and storage, the leaves must be dried since the degradation of the compounds begins and consequently, its therapeutic activity decreases (Avello-Lorca et al., 2011). An ideal method for drying medicinal leaves should offer shorter heating time, lead to greater nutrient retention and improve quality characteristics (Di Cesare et al., 2003).

Different drying methods have been used to preserve the leaves longer, ensuring their availability during off-season. These methods can be classified into thermal drying and special drying (Babu et al., 2018). For example, natural and forced convection drying methods are within thermal drying while microwaveassisted drying is among special drying. In natural convection drying, the natural air circulation is used together with an increased temperature in a closed room. The energy used is low but the drying periods are normally high. Forced convection can significantly reduce the drying time by removing more moisture and transferring a higher percentage of previously heated air to the drying chamber (Amedorme et al., 2013). Microwave-assisted drying propagates electromagnetic energy through space by variable electric and magnetic fields. Food products response to dielectric heating result in rapid energy coupling inside the moisture, thus ensuring faster heating and drying (Feng et al., 2012).

The most of herbals and leaves have been dried using mainly the processes of forced convection and solar drying. Solar dryers may be used only about 4 months a year due to the cold and high relative humidity (Pinela et al., 2011). There are no studies of drying process behavior for energy consumption and the final quality of these leaves. The use of drying parameters such as drying time and drying temperature without considering the food characteristics (leaf thickness, diffusion coefficient, types of volatile active compounds, etc.) can result in loss of quality and nutrient constituents during the process (Feng et al., 2012; Amedorme et al., 2013; Hussein et al., 2015; Babu et al., 2018). Alternative methods to the conventional drying such microwave drying and/or combination thereof can contribute to improve leaves quality. This way, the processes could be more rapid, more uniform, energy efficient, along with keeping interest components of the leaves (Vadivambal and Jayas, 2007). The microwave technology is very required because present a high heating capacity not only on the surface but also inside the food what implies speed up the drying process and decreasing time process (Pinela et al., 2011).

Furthermore, there are few researches regarding the application of drying methods on K. oblonga leaves and further evaluating process parameters and leaves quality. Thereby, the aim of this study was to evaluate several drying technologies (vacuum drying, natural convection, forced convection, and forced convection assisted by microwave methods) and study how these techniques affect to processing time, drying kinetic behavior, energy consumption as well as biocompounds content (phenols and proximal) in K. oblonga leaves.

\section{MATERIALS AND METHODS}

\section{Raw Material}

The K. oblonga leaves were obtained in the locality of Rauco, Cuesta La Higuera, Region of Maule, Chile (34⒌ $56^{\prime} 43^{\prime \prime} S$; $\left.71^{\circ} 21^{\prime} 51^{\prime \prime} \mathrm{W}\right)$, in the month of May. Once collected, these were refrigerated at $5.0 \pm 0.2^{\circ} \mathrm{C}$ until used. This way, the moisture, ash, lipids, crude fiber, protein, and carbohydrate analyses were performed on fresh and dried $K$. oblonga leaves samples. The used methodologies were those recommended by the AOAC (AOAC, 1990).

\section{Drying Methods}

Four drying methods were applied to $K$. oblonga leaves were oven drying, vacuum drying, convective drying, and microwaveassisted convective drying. The drying methods were performed in the different dryer used, as Figure 1 shows. The weight of the sample and therefore the moisture content was measured every $5 \mathrm{~min}$ in all cases. Each drying method applied until the final equilibrium moisture values were achieved.

- Oven drying (NC): This drying method is applied to fresh leaves of, subjected to different temperatures of 60,80 , and $100^{\circ} \mathrm{C}$. The drying times, according to the used temperatures, were of 240, 180, and $135 \mathrm{~min}$, respectively. An oven model LDO- 080F (Mlab Scientific) was used.

- Vacuum drying (VNC): The process is similar to the previous one, but with added vacuum. The Mlab Scientific Vacuum Oven MVO-024 was used to perform the test together with the vacuum pump Rocket 400 . Temperatures of 60 and $80^{\circ} \mathrm{C}$ and a vacuum pressure of $0.08 \mathrm{MPa}$ were applied.

- Convective drying (FC): This method was performed with a convective dryer manufactured by the University of Talca, which consists of a wind tunnel with an electric heater that heats the air entering to a rectangular chamber. This equipment corresponds to a modified commercial microwave, which can perform both the FC and MWFC processes. In the rectangular cavity where $\mathrm{FC}$ drying takes place, the magnetron that produces the microwaves was not activated. The air temperature is controlled by an Arduino sensor connected a computer. Air speed was constant in all tests $(1.7 \mathrm{~m} / \mathrm{s})$ and the air temperatures were 70,80 , and $90^{\circ} \mathrm{C}$. A relative humidity sensor, located at the entrance of the equipment, measured the relative humidity and its value was $47.3 \pm 5.5 \%$.

- Microwave-assisted convective drying (MWFC): The same equipment of the FC was used but, in this case, the magnetron was operated with two microwave powers (720 and 1,120 W). The applied air velocity is the same as for the FC and two different air temperatures of 40 and $20^{\circ} \mathrm{C}$ were applied.

\section{Diffusivity and Modeling}

For each drying process, the effective moisture diffusivity $\left(D_{\text {eff }}\right)$ of the $K$. oblonga leaves were determined by Fick's second law which is based on the moisture ratio $(M R$, Eq. 1), where this one relates the gradient of the sample moisture content in real time $\left(X_{t}\right)$ to both initial $\left(X_{i}\right)$ and equilibrium $\left(X_{e}\right)$ moisture content (Vega-Gálvez et al., 2014). The integrated equation of 
A

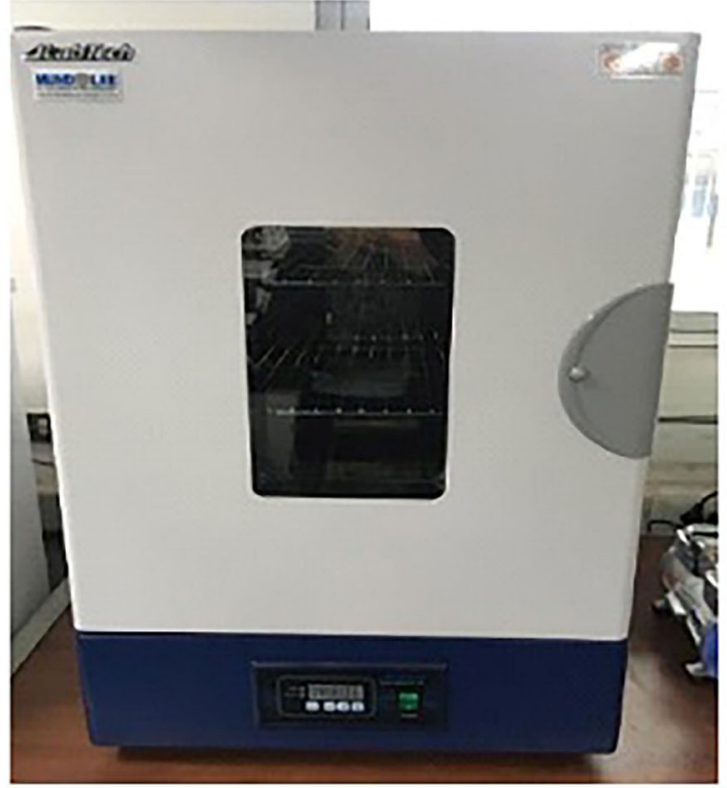

B

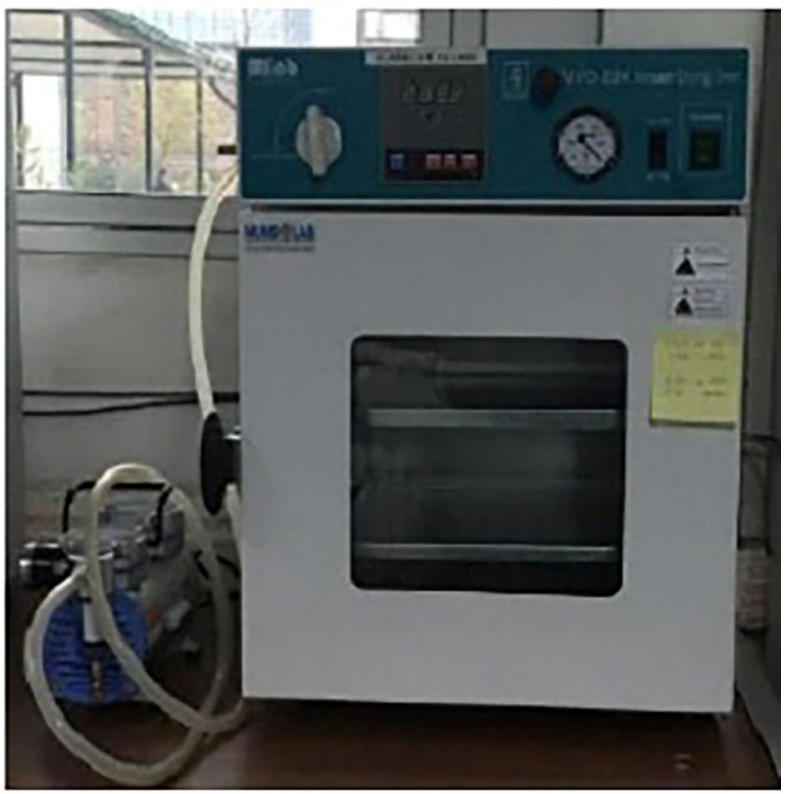

C

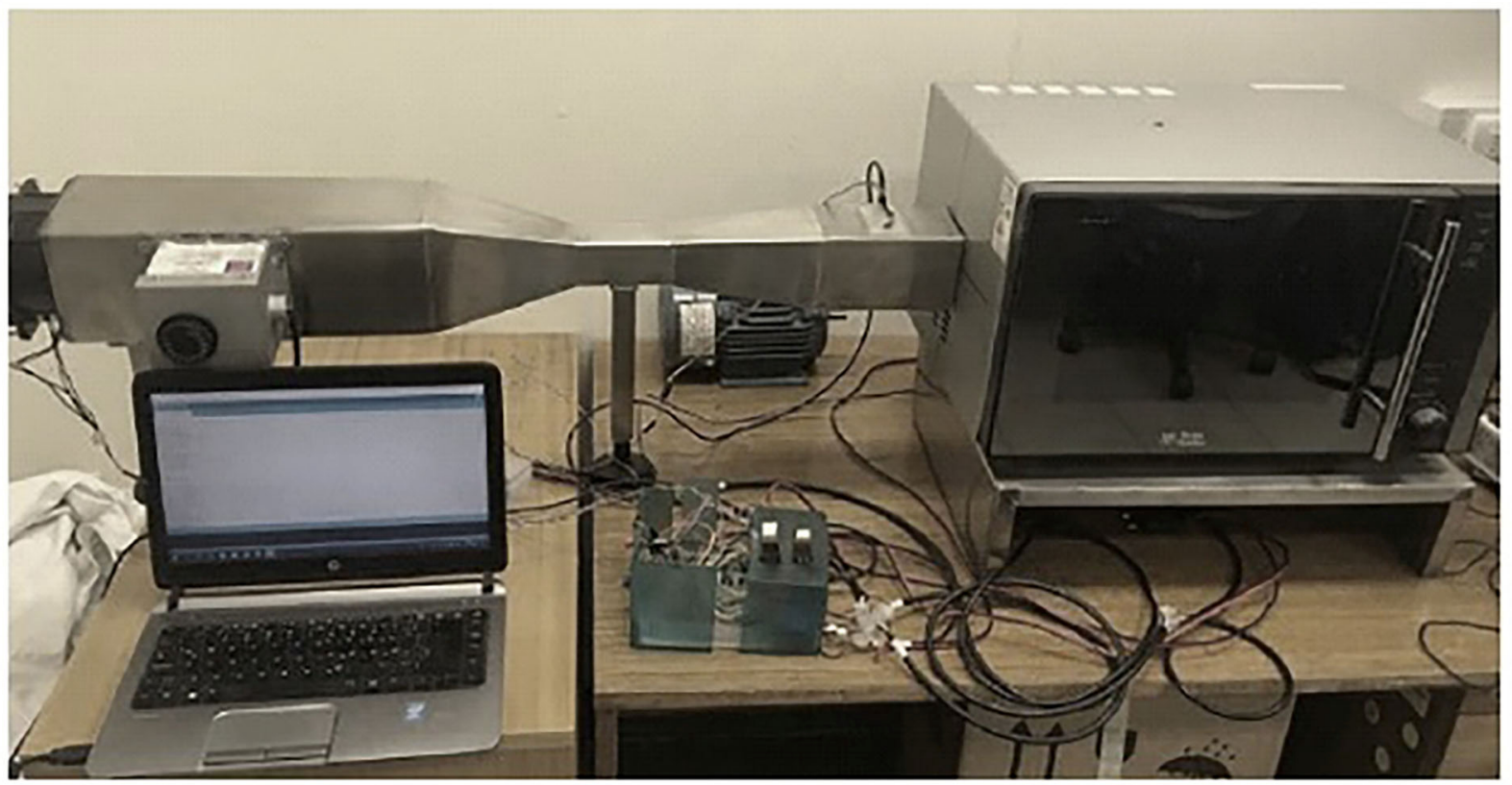

FIGURE 1 | Different dryers used for this study: (A) Oven dryer (NC), (B) vacuum dryer (VNC), and (C) convective (FC) and microwave-assisted convective dryer (MWFC) assisted convective dryer (MWCD).

Fick's second law was also used for long time periods and thinlayer in one dimension (Eq. 2) which leads to Eq. (3), representing the first term in the development of the series, from which the diffusional coefficient is obtained for each drying process (Lemus-Mondaca et al., 2015). The equilibrium moisture content $\left(X_{e}\right)$ was determined experimentally by monitoring the weight and calculating the leaves moisture content using an analytical balance (Chyo, modelo JK-200) and from the calculation of the absolute value between two consecutive moisture measurements according to the following criterion, $\left(\mathrm{X}_{\mathrm{t}}+\mathrm{X}_{\mathrm{t}+1}\right)<0.001$, where $\mathrm{X}_{\mathrm{t}+1}$ is the moisture content at time $t+1$ (Togrul and Pehlivan, 2003).

$$
\begin{aligned}
M R & =\frac{X_{t}-X_{e}}{X_{o}-X_{e}} \\
M R & =\sum_{i=0}^{\infty} \frac{8}{(2 i+1)^{2} \pi^{2}} \exp \left(\frac{-D_{e f f}(2 i+1)^{2} \pi^{2} t}{4 L^{2}}\right)
\end{aligned}
$$




$$
M R=\frac{8}{\pi^{2}} \exp \left(\frac{-D_{e f f} \pi^{2} t}{4 L^{2}}\right)
$$

Where: $L$ is the leaves average thickness $(\mathrm{m}), i$ is number of terms; and $t$ is time ( $\mathrm{min})$.

Several mathematical models have been proposed to describe the characteristic drying curves of food and agricultural products. In this work, the Weibull (Eq. 4) and Midillli-Kucuk (Eq. 5) models were used (Hussein et al., 2015; Lemus-Mondaca et al., 2016).

$$
\begin{aligned}
M R & =\exp \left[-(t / \beta)^{\alpha}\right] \\
M R & =n_{1} \exp \left(-k t^{n_{2}}\right)+c t
\end{aligned}
$$

Where: $k, n_{1}, n_{2}$ and $c$ represent empirical parameters of MidilliKucuk model, whereas $\alpha$ is shape parameter (dimensionless) and $\beta$ is scale parameter $(1 / \mathrm{min})$ of Weibull model.

The accumulative relative error (RE\%, Eq. 6) between the experimental and predicted data is obtained with the following equation:

$$
R E \%=\sum_{i=0}^{\infty} \frac{\left|M R_{\bmod }-M R_{\exp }\right|}{M R_{\exp }} \times 100
$$

Here the sub-script $M R_{\text {mod }}$ and $M_{\text {exp }}$ indicate the modeled and experimental values at time $t$, respectively.

\section{Energetic Aspects}

To calculate the energy consumption $\left(E_{C}, \mathrm{~kW} \cdot \mathrm{h}\right)$, the electric energy used by the equipment was considered together with the duration of the drying tests (Motevali et al., 2011).

$$
\begin{aligned}
E_{C, N C} & =\left(P \cdot h_{c}\right)+\left(P \cdot h_{s}\right) \\
E_{C, V N C} & =P \cdot\left(h_{c}+h_{s}\right)+\left(P_{B} \cdot h_{B}\right) \\
E_{C, F C} & =\left(P_{a i} \cdot h_{a i}\right)+\left(P_{e x} \cdot h_{e x}\right)+\left(P_{r s} \cdot h_{r s}\right) \\
E_{C, M W F C} & =\left(P_{a i} \cdot h_{a i}\right)+\left(P_{e x} \cdot h_{e x}\right)+\left(P_{r s} \cdot h_{r s}\right) \\
& +\left(P_{M W} \cdot h_{M W}\right)
\end{aligned}
$$

Where, $P$ is the electrical power of the oven $(\mathrm{kW}) ; h_{c}$ is the warmup time of the equipment (h); $h_{s}$ is the drying time (h); $P_{B}$ is the electric power of the vacuum pump $(\mathrm{kW}) ; h_{B}$ is the running time of the vacuum pump $(\mathrm{h}) ; P_{r s}$ is the electrical resistance power of hot-air $(\mathrm{kW}), P_{a i}$ is the fans power that drive the air $(\mathrm{kW})$ and $P_{e x}$ is the air extractor power $(\mathrm{kW})$ and $P_{M W}$ is the microwave power $(\mathrm{kW})$, for the respective usage time (h).

In all drying methods the energy efficiency ( $\eta$, Eq. 11), of the process was calculated using the following equation which was calculated the instantaneous yield (Menshutina et al., 2004).

$$
\eta=\frac{m_{w} \cdot \lambda_{w}}{E_{C} \cdot 3600}
$$

Where $\eta$ is the percentage energy efficiency (\%), $m_{w}$ is the mass of evaporated water $(\mathrm{kg}), \lambda_{\mathrm{w}}$ is the latent heat of vaporization $(2,257 \mathrm{~kJ} / \mathrm{kg})$ and $E_{T}$ is the total energy consumed by the equipment or energy consumption in the total drying period $(\mathrm{kW} \cdot \mathrm{h})$.

\section{Polyphenols and Proximal Analysis}

Firstly, an aqueous extract of Kageneckia oblonga leaves was performed based on the methodology by Taralkar and Chattopadhyay (2012) with some modifications. To $5 \mathrm{~g}$ of fresh and dried leaves, then $100 \mathrm{~mL}$ of methanol are added. The sample was stirred at a temperature of $28^{\circ} \mathrm{C} \times 2 \mathrm{~h}$, and then filtered. The obtained liquid was kept refrigerated at $5^{\circ} \mathrm{C}$ until analysis. As to TPC quantification, the Folin-Ciocalteu method was used. To $0.1 \mathrm{~mL}$ of aqueous extract, $0.5 \mathrm{~mL}$ of FolinCiocalteu reagent is added along with $1.5 \mathrm{~mL}$ of $20 \%$ sodium carbonate. After $2 \mathrm{~h}$ the dark the absorbance was measured in a spectrophotometer (Optizen Pop). A calibration curve based on gallic acid (GAE) was used which is expressed in mg GAE/L. As for the Identification of phenolic compounds, a High-resolution mass spectrometer Exactive ${ }^{\mathrm{TM}}$ Plus Orbitrap, ThermoFisher Scientific (Bremen, Germany) was used. The scan parameters were following: Resolution: 140,000, AGC target: 3E6, Max. inject time: 200, HESI source: Sheath gas flow: 45, Aux gas flow rate: 20 , Sweep gas flow rate: 0 , Capillary temperature: $350^{\circ} \mathrm{C}$, S-lens RF level: 0, Heater temperature: $200^{\circ} \mathrm{C}$. Identification of selected phenolic compounds was obtained by comparison of retention times, spectra, and peak area at a maximum absorption wavelength to standards. As for proximal analysis, a natural convection oven was used to measure the initial moisture content (Mlab Scientific LDO- 080F) in which the sample was kept at $80^{\circ} \mathrm{C} \times 14 \mathrm{~h}$. The ashes were determined using a muffle (Vulcan model A-550) where the sample was kept at $550^{\circ} \mathrm{C} \times 12 \mathrm{~h}$. Lipids were measured by the Soxhlet method and crude fiber with a fiber extractor (Velp, model fiwe 6). The protein was measured by the Kjeldahl method with a conversion factor of 6.25. Carbohydrates were obtained by difference between the values of the previous results and $100 \%$. The average thickness of leaves was measured with a Vernier caliper (500-144, Mitutoyo Digimatic Caliper, China). All analyses were performed in triplicate and expressed in $\mathrm{g} / 100 \mathrm{~g}$ dry matter (d.m.).

\section{Statistical Analysis}

An analysis of variance (ANOVA) was performed for diffusivities, empirical parameters, equilibrium moisture, and proximal values at a confidence level of 95\% ( $p$-value $<0.05)$ by software StatGraphics ${ }^{\circledR}$ Centurion, including a Multiple Range Test (MRT) to recognize significant differences among each drying condition to determine possible homogeneous groups.

\section{RESULTS}

\section{Dried $K$. oblonga Leaves}

A relevant factor to consider in addition to drying kinetics and energy consumption is the appearance of the $K$. oblonga leaves after each drying process. Figure 2 presents final state pictures of the leaves considering the different drying methods and conditions used. The conditions observed were $\mathrm{NC}$ at 100 , 80 , and $60^{\circ} \mathrm{C}$, VNC at 80 and $60^{\circ} \mathrm{C}, \mathrm{FC}$ at 90,80 , and $70^{\circ} \mathrm{C}$, and $\mathrm{MWFC}$ at $700 \mathrm{~W} / 40^{\circ} \mathrm{C}, 1,120 \mathrm{~W} / 20^{\circ} \mathrm{C}$, and $1,120 \mathrm{~W} / 40^{\circ} \mathrm{C}$. 


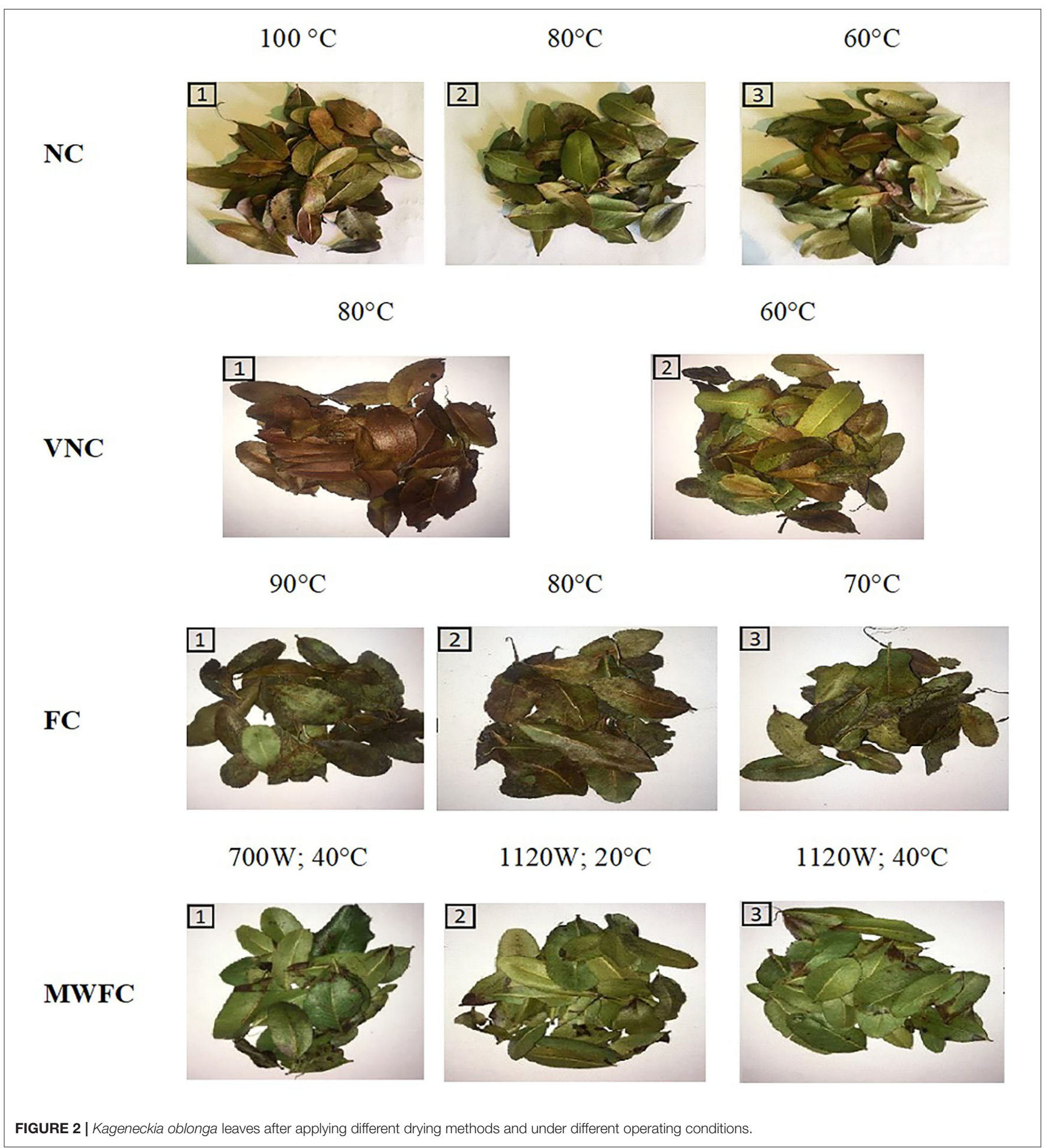

\section{Drying Curves Behavior}

The moisture content values with different methods and the drying time to reach the equilibrium moisture content are presented in Table 1. The drying kinetics for each drying method is presented in Figure 3. It was observed that the leaves moisture content decreases faster when the air temperature is higher.
The drying time to reach the equilibrium moisture content $\left(X_{e}\right)$ was between 30-120 and 60-90 min for the NC and FC drying processes, respectively, under temperatures from 60 to $100^{\circ} \mathrm{C}$ (Table 1). When statistically evaluating equilibrium moisture content $\left(X_{e}\right)$, the ANOVA results indicated that comparing $X_{e}$ values presented a significant effect of drying conditions 
on this value $(p$-value $<0.05)$. The MRT also stated that eight homogeneous groups for each used drying temperature were found (Table 1). Figure 3 shows the drying kinetics of VNC method, this shows a long time to reach the equilibrium condition (over $400 \mathrm{~min}$ ) both 60 and $80^{\circ} \mathrm{C}$ (Table 1). Figure 3 also shows the drying curves obtained by adding microwaves to forced convection drying.

\section{Diffusivity and Modeling}

Different values range for $D_{\text {eff }}$ were obtained for each drying method. For NC, VNC, FC, and MWFC methods the $D_{\text {eff }}$ ranges were of $3.94-8.14 \times 10^{-11} \mathrm{~m}^{2} / \mathrm{s}, 1.12-1.40 \times 10^{-11}$ $\mathrm{m}^{2} / \mathrm{s}, 7.83-11.36 \times 10^{-11} \mathrm{~m}^{2} / \mathrm{s}$ and $6.93-16.72 \times 10^{-11} \mathrm{~m}^{2} / \mathrm{s}$, respectively. The values obtained of $D_{\text {eff }}$ during FC method were

TABLE 1 | Drying times, equilibrium moisture content, equilibrium time, and diffusivity coefficient obtained in each drying method.

\begin{tabular}{lcccc}
\hline Drying method & $\mathbf{T}_{\mathbf{a}}\left({ }^{\circ} \mathbf{C}\right)$ & $\boldsymbol{X}_{\boldsymbol{e}}(\boldsymbol{\%})$ & $\boldsymbol{t}_{\boldsymbol{e}}(\mathbf{m i n})$ & $\boldsymbol{D}_{\text {eff }} \times \mathbf{1 0}^{\mathbf{- 1 1}} \mathbf{( m}^{\mathbf{2} / \mathbf{s})}$ \\
\hline NC & 60 & $19.00 \pm 1.41^{\mathrm{a}}$ & 120 & $3.94 \pm 0.88^{\mathrm{e}}$ \\
& 80 & $17.89 \pm 1.73^{\mathrm{ab}}$ & 45 & $5.93 \pm 0.4^{\mathrm{d}}$ \\
& 100 & $16.61 \pm 0.43^{\mathrm{b}}$ & 30 & $8.14 \pm 0.7^{\mathrm{c}}$ \\
VNC & 60 & $22.05 \pm 0.40^{\mathrm{c}}$ & 520 & $1.40 \pm 0.28^{\dagger}$ \\
& 80 & $19.80 \pm 3.38^{\mathrm{bc}}$ & 420 & $1.12 \pm 0.15^{\dagger}$ \\
FC & 70 & $24.07 \pm 0.28^{\mathrm{d}}$ & 90 & $7.83 \pm 1.42^{\mathrm{c}}$ \\
& 80 & $21.42 \pm 0.25^{\mathrm{c}}$ & 75 & $7.49 \pm 1.45^{\mathrm{c}}$ \\
& 90 & $21.06 \pm 1.77^{\mathrm{bc}}$ & 60 & $11.36 \pm 1.1^{\mathrm{b}}$ \\
MWFC-700W & 40 & $17.74 \pm 1.98^{\mathrm{e}}$ & 30 & $16.72 \pm 2.3^{\mathrm{a}}$ \\
MWFC-1,120W & 20 & $17.53 \pm 0.04^{\mathrm{e}}$ & 10 & $12.63 \pm 1.23^{\mathrm{b}}$ \\
& 40 & $15.47 \pm 1.01^{\dagger}$ & 10 & $6.93 \pm 2.30^{\mathrm{c}}$ \\
\hline
\end{tabular}

Different letters $(a, b)$ in the same line indicate significant differences $(p \leq 0.05)$. comparable with those reported by Panchariya et al. (2002) for convective drying of black tea leaves $\left(D_{\text {eff: }} 1.14-2.98 \times 10^{-11}\right.$ $\mathrm{m}^{2} / \mathrm{s}$, air-velocity: $0.25-0.65 \mathrm{~m} / \mathrm{s}$, temperature: $80-120^{\circ} \mathrm{C}$ ), Park et al. (2002) for convective drying of mint leaves $\left(D_{\text {eff: }} 0.47-\right.$ $2.94 \times 10^{-12} \mathrm{~m}^{2} / \mathrm{s}$, air temperature and velocity of $30-50^{\circ} \mathrm{C}$ and $0.5-1.0 \mathrm{~m} / \mathrm{s}$, respectively) and Lemus-Mondaca et al. (2015) for Stevia leaves dried by convective drying $\left(D_{\text {eff: }} 0.81-8.49 \times\right.$ $10^{-11} \mathrm{~m}^{2} / \mathrm{s}$, air-temperature: $30-80^{\circ} \mathrm{C}$ and air-velocity: $2 \mathrm{~m} / \mathrm{s}$ ). Other studies showed higher diffusivities, such as Doymaz (2006) that evaluated the mint leaves convective drying (air-velocity: $4.1 \mathrm{~m} / \mathrm{s}$ and air-temperature: 35 and $60^{\circ} \mathrm{C}$ ), and presented $D_{\text {eff }}$ values between 0.31 and $1.94 \times 10^{-8} \mathrm{~m}^{2} / \mathrm{s}$; Doymaz (2006) in dill $\left(D_{\text {eff: }} 0.66-1.43 \times 10^{-9}\right)$ and parsley $\left(D_{\text {eff: }} 0.90-2.33 \times 10^{-9}\right)$ by hot-air drying (air-velocity: $1.1 \mathrm{~m} / \mathrm{s}$, air-temperature: $50-70^{\circ} \mathrm{C}$ ), Kaya (2009) working with nettle $\left(D_{\text {eff: }} 1.74-4.99 \times 10^{-9}\right)$ and mint leaves $\left(D_{\text {eff }}: 1.975-6.172 \times 10^{-9}\right)$ during convective drying (air-velocity: $0.2-0.6 \mathrm{~m} / \mathrm{s}$, air-temperature: $35-55^{\circ} \mathrm{C}$ ). The $D_{\text {eff }}$ values for MWFC drying process (180-900 W) are comparable with the ones obtained by Özbek and Dadali (2007) for mint leaves, $D_{\text {eff: }} 3.16-9.25 \times 10^{-11} \mathrm{~m}^{2} / \mathrm{s}$. When evaluating the $D_{\text {eff }}$ values by ANOVA analysis at a confidence level of $95 \%$, this analysis showed a significant effect of drying temperature on the $D_{\text {eff }}$ values (i.e. $p$-value $<0.05$ ). As for the MRT analysis, which determines if there are differences significant among the $D_{\text {eff }}$ means values, it was shown five homogeneous groups for each drying temperature, as follows: NC60; VNC60-VNC80; MWFC700W (40); MWFC1120W (40)-FC80; MWFC1120W (20)-FC90-FC70-NC100; NC80. The values of the parameters used to model the drying curves according to the Weibull and Midilli-Kucuk models are presented in Table 2.

\section{Statistical Analysis of Models}

Figure 3 shows the experimental drying data along with the drying curves calculated with the mathematical models that

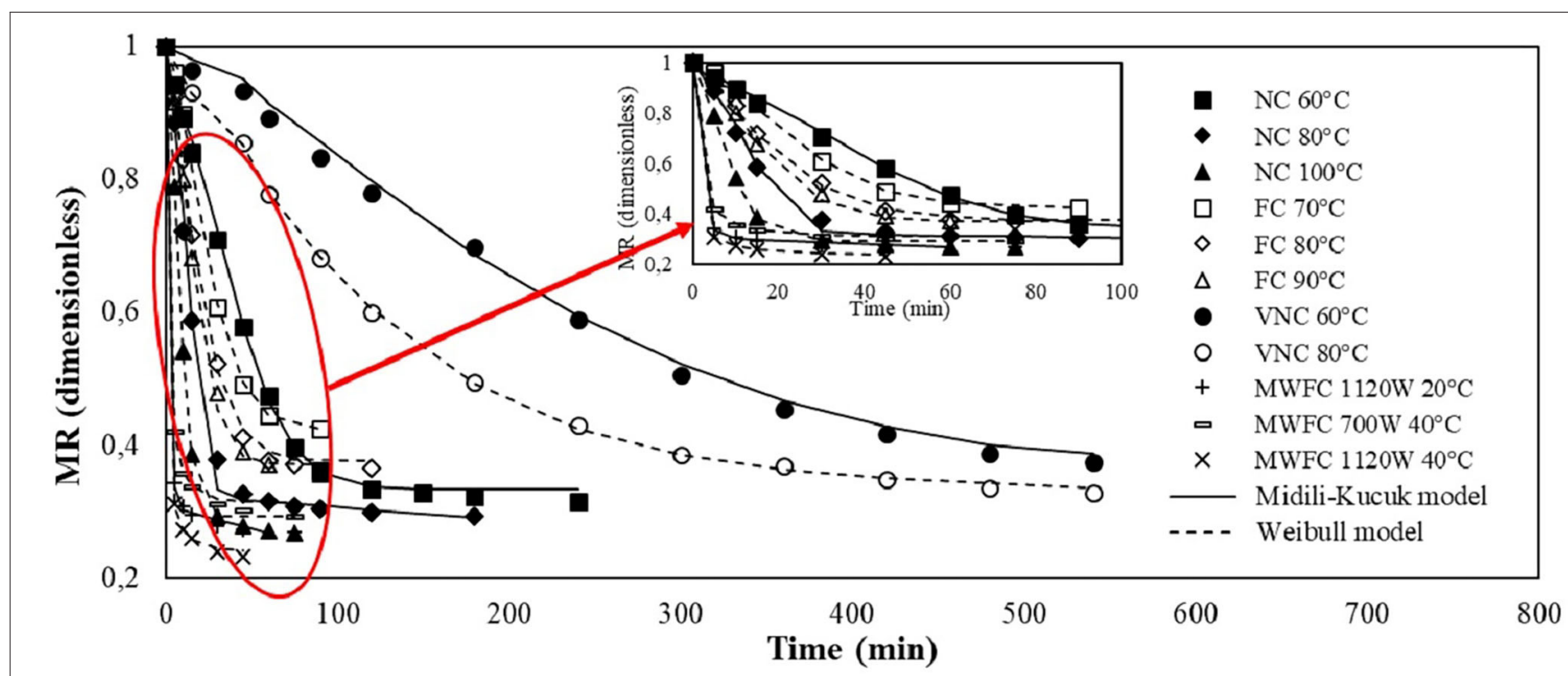

FIGURE 3 | Drying curves predicted by Midilli-Kucuk and Weibull models with the lowest RE values for each drying curve. 
TABLE 2 | Empirical parameter values for each temperature and drying method.

\begin{tabular}{|c|c|c|c|c|c|}
\hline $\begin{array}{l}\text { Drying } \\
\text { method }\end{array}$ & $\mathbf{T}_{\mathrm{a}}\left({ }^{\circ} \mathbf{C}\right)$ & $\begin{array}{l}\text { Weibull } \\
\text { model }\end{array}$ & RE & Midilli-Kucuk model & RE \\
\hline \multirow[t]{6}{*}{ NC } & 60 & $\alpha=1.54$ & 33.02 & $\begin{array}{c}n_{1}=0.89 ; n_{2}=1.84 \\
c=1 \times 10^{-8} \\
k=8 \times 10^{-4}\end{array}$ & 22.56 \\
\hline & & $\beta=43.02$ & & & \\
\hline & 80 & $\alpha=1.44$ & 40.36 & $\begin{array}{c}n_{1}=0.89 ; n_{2}=2.22 \\
c=-3 \times 10^{-4} \\
k=0.002\end{array}$ & 24.31 \\
\hline & & $\beta=15.54$ & & & \\
\hline & 100 & $\alpha=1.6$ & 37.16 & $\begin{array}{c}n_{1}=0.83 ; n_{2}=3.15 \\
c=-4 \times 10^{-4} \\
k=0.006\end{array}$ & 43.44 \\
\hline & & $\beta=9.58$ & & & \\
\hline \multirow[t]{4}{*}{ VNC } & 60 & $\alpha=1.5$ & 48.68 & $\begin{array}{c}n_{1}=0.96 ; n_{2}=1.44 \\
c=-2 \times 10^{-4} \\
k=4 \times 10^{-4}\end{array}$ & 12.75 \\
\hline & & $\beta=197$ & & & \\
\hline & 80 & $\alpha=1.155$ & 11.61 & $\begin{array}{c}n_{1}=0.905 ; n_{2}=1.48 \\
c=1 \times 10^{-6} \\
k=6.2 \times 10^{-4}\end{array}$ & 37.64 \\
\hline & & $\beta=131$ & & & \\
\hline \multirow[t]{6}{*}{ FC } & 70 & $\alpha=1.55$ & 5.17 & $\begin{array}{c}n_{1}=0.91 ; n_{2}=2.14 \\
c=-1 \times 10^{-5} \\
k=7 \times 10^{-4}\end{array}$ & 16.77 \\
\hline & & $\beta=28$ & & & \\
\hline & 80 & $\alpha=1.34$ & 15.02 & $\begin{array}{c}n_{1}=0.9 ; n_{2}=2.32 \\
c=5 \times 10^{-4} \\
k=-4 \times 10^{-5}\end{array}$ & 33.06 \\
\hline & & $\beta=21.95$ & & & \\
\hline & 90 & $\alpha=1.55$ & 13.41 & $\begin{array}{c}n_{1}=0.9 ; n_{2}=2.25 \\
\quad c=1 \times 10^{-5} \\
k=8 \times 10^{-4}\end{array}$ & 34.66 \\
\hline & & $\beta=19$ & & & \\
\hline \multirow[t]{2}{*}{ MWFC-700W } & 40 & $\alpha=0.5$ & 20.62 & $\begin{array}{c}n_{1}=0.9 ; n_{2}=4.85 \\
c=-1 \times 10^{-5} \\
k=7 \times 10^{-4}\end{array}$ & 42.88 \\
\hline & & $\beta=1.4$ & & & \\
\hline \multirow[t]{4}{*}{ MWFC-1,120W } & W 20 & $\alpha=0.485$ & 48.01 & $\begin{array}{c}n_{1}=1 ; n_{2}=3.85 \\
c=-1 \times 10^{-3} \\
k=6.2 \times 10^{-3}\end{array}$ & 10.81 \\
\hline & & $\beta=0.5$ & & & \\
\hline & 40 & $\alpha=0.38$ & 8.4 & $\begin{array}{c}n_{1}=0.91 ; n_{2}=3.85 \\
c=-1 \times 10^{-4} \\
k=4.5 \times 10^{-3}\end{array}$ & 31.56 \\
\hline & & $\beta=0.5$ & & & \\
\hline
\end{tabular}

obtained the lowest relative error values. The lowest RE\% values are obtained by using the Weibull model for the drying processes following: $\mathrm{NC} 100^{\circ} \mathrm{C}$, $\mathrm{VNC} 80^{\circ} \mathrm{C}, \mathrm{FC} 70^{\circ} \mathrm{C}, \mathrm{FC} 80^{\circ} \mathrm{C}, \mathrm{FC} 90^{\circ} \mathrm{C}$, $\mathrm{MWFC} 1120 \mathrm{~W} / 40^{\circ} \mathrm{C}$ and $\mathrm{MWFC} 700 \mathrm{~W} / 40^{\circ} \mathrm{C}$. The $\mathrm{RE} \%$ values varied between 5.2 and $37.2 \%$. Whereas, the Midilli-Kucuk model gave the lowest values of RE\% for $\mathrm{NC} 60^{\circ} \mathrm{C}$, NC $80^{\circ} \mathrm{C}$, VNC $60^{\circ} \mathrm{C}$, and MWFC $1120 \mathrm{~W} / 40^{\circ} \mathrm{C}$. In these cases, the $\mathrm{RE} \%$ values ranged between 10.8 and $24.3 \%$.

\section{Energy Consumption}

The results of the energy consumption and operating condition of each studied drying process are presented in Figure 4. In general, the shorter the time to reach the equilibrium condition, the lower is the energy consumption.

\section{Proximal, Polyphenols, and Interesting Compounds}

A proximal analysis comparison was performed on samples of fresh leaves and those obtained after having gone through the MWFC drying process with a microwave power of $1120 \mathrm{~W}$ and an air temperature of $20^{\circ} \mathrm{C}$, these results were shown in Table 3. The initial moisture content values $(130.79 \pm 0.07 \mathrm{~g} / 100 \mathrm{~g}$ d.m.) are close to those reported by Montenegro et al. (1980) in fresh leaves $(133.998 \pm 0.21 \mathrm{~g} / 100 \mathrm{~g}$ d.m.). As for, the total polyphenol content for the fresh and MWFC-dried leaves, values of $18.62 \pm 0.27$ and $25.87 \pm 1.103 \mathrm{mg} \mathrm{GAE} / \mathrm{g}$ d.m. were obtained, respectively. The $K$. oblonga leaves have a high content of total polyphenol content, comparable to the leaves of the olive tree (Picual variety: $83.3 \pm 3.15 \mathrm{mg} / \mathrm{g}$ d.m., Arbequina variety: 46.04 $\pm 1.94 \mathrm{mg} / \mathrm{g}$ d.m. and Sikitita variety: $53.68 \pm 2.98 \mathrm{mg} / \mathrm{g}$ d.m.) (Talhaoui et al., 2016).

From the methanol extract, isolations were performed of interesting compounds, these were identified according to the peak characteristics, such as retention time, a wavelength of maximum absorption, and mass spectral data. Two compounds were identified, as shown in Figure 5.

\section{DISCUSSION}

\section{Dried $K$. oblonga Leaves}

The Figure 2 shows that during $\mathrm{NC}$ drying at $100^{\circ} \mathrm{C}$, leaves were damaged by the temperature, these operating conditions alters the initial green color of the leaves. The green appearance of the fresh leaf was less affected when the air temperature is lowered, even though there are a few which get brown during this drying process ( $\mathrm{NC}$ at 80 and $60^{\circ} \mathrm{C}$ ). Also, this figure shows the leaves resulting from the $\mathrm{VNC}$ drying process, at $80^{\circ} \mathrm{C}$ air temperature it was observed that all leaves of the sample have a brown color, which indicates temperature damage. Whereas, at $60^{\circ} \mathrm{C}$ there were $K$. oblonga leaves that maintain their green color, however there were still some brown leaves that were damaged mainly by the mixture between temperature and high residence time during the process. During VNC drying, severe damage was observed when the leaves were dried at $100^{\circ} \mathrm{C}$. Due to this assay, the results are not presented at this temperature. During the FC process, some brown leaves could be observed, which indicate damage due to the high temperature of the applied air. When working at $70^{\circ} \mathrm{C}$, the damage by temperature observed by the brown color of the leaves decreased. The dried leaves obtained with the MWFC process do not have visible damage by temperature and the original green color is better preserved. This could be attributed to the fact that during this method the leaves are exposed to shorter drying time and lower air temperatures. Shorter heating time also leads to greater nutrient retention, better quality characteristics such as texture, color and flavor, as well as increased production (Doymaz, 2006). That is why, the 


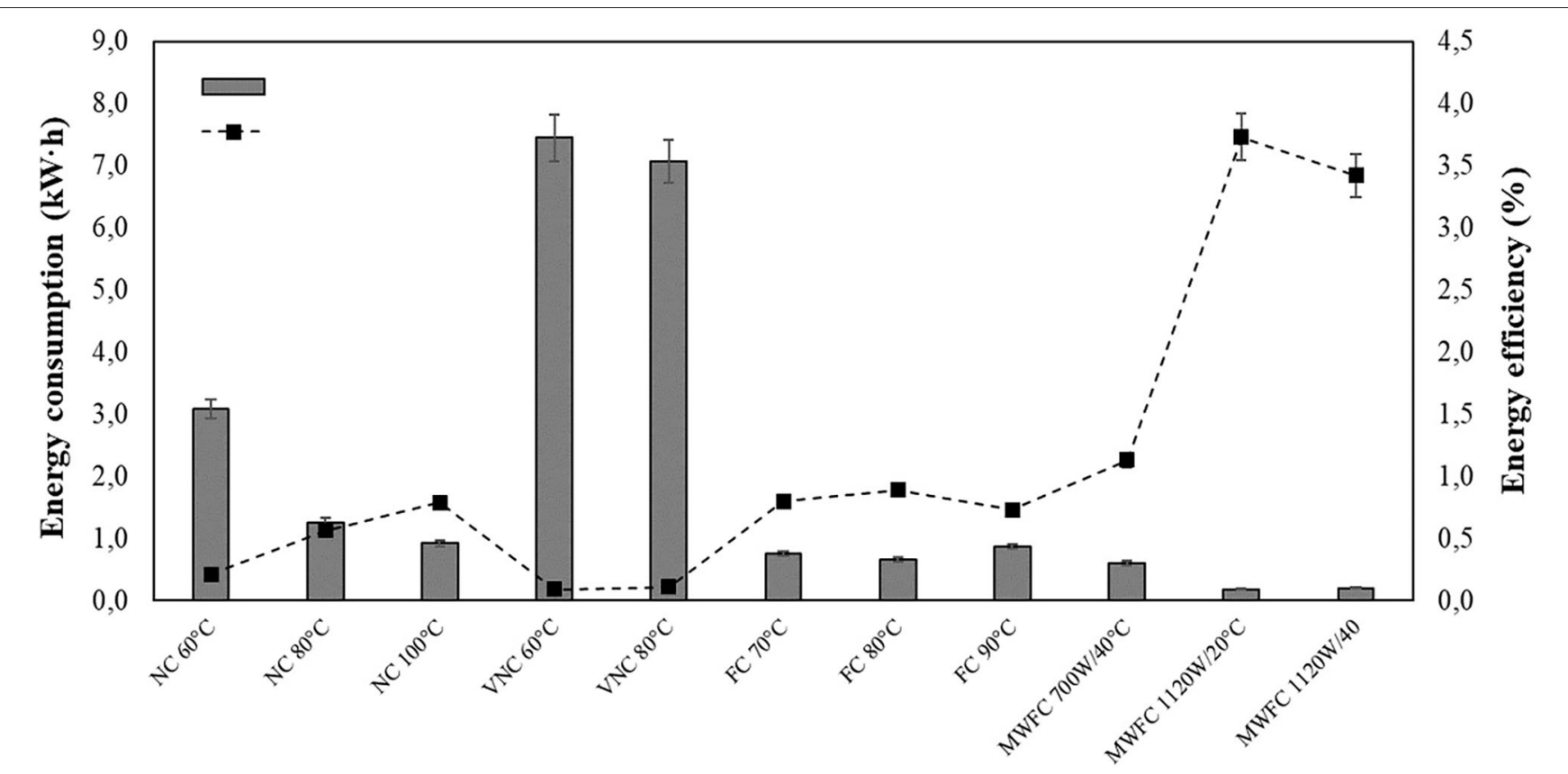

FIGURE 4 | Effect of different drying methods on energy consumption and efficiency of Kageneckia oblonga leaves drying.

TABLE 3 | Proximal analysis of fresh Kageneckia oblonga "Bollén" leaves and microwave-assisted convective dried (MWFC $1,120 \mathrm{~W} / 20^{\circ} \mathrm{C}$ ).

\begin{tabular}{lcc}
\hline Proximal analysis* $^{*}$ & Fresh $\boldsymbol{K}$. Oblonga leaf & Dried $\boldsymbol{K}$. Oblonga leaf \\
\hline Moisture & $130.79 \pm 0.07$ & $2.51 \pm 0.21$ \\
Lipid & $2.50 \pm 0.25$ & $2.73 \pm 0.27$ \\
Total ash & $6.71 \pm 0.22$ & $7.45 \pm 0.63$ \\
Protein & $15.54 \pm 0.35$ & $11.74 \pm 0.22$ \\
Crude fiber & $41.99 \pm 1.95$ & $60.83 \pm 1.8$ \\
Carbohydrates & $33.26 \pm 0.66$ & $17.25 \pm 0.52$ \\
\hline
\end{tabular}

${ }^{*}(g / 100 \mathrm{~g}$ d.m) .

microwaves didn't not visibly affect the original green color of the leaves. Thus, a reduced time during drying and a high moisture effective diffusion would play an important role in the selection of the method to use to dry these leaves.

\section{Drying Curves Behavior}

Regarding the drying time of VNC process, this showed the highest average time of all drying methods. The drying times reached were above $400 \mathrm{~min}$ with regard to the average time for each drying method. Whilst the drying time reached by MWFC process, both drying conditions (MWFC $700 \mathrm{~W} / 20^{\circ} \mathrm{C}$ and MWFC $1,120 \mathrm{~W} / 20^{\circ} \mathrm{C} / 40^{\circ} \mathrm{C}$ ) presented an average drying time close to $20 \mathrm{~min}$. A similar tendency was found for equilibrium moisture content values since the lower $X_{e}$ values were obtained for MWFC and NC methods $\left(15.5<X_{e}<19.0\right)$ while higher $X_{e}$ values were obtained for VNC and FC method $\left(19.8<X_{e}<24.1\right)$. Also, no difference was found between these two drying methods that might be due to the fact that both methods were applied under temperatures very close. From the same Figure 3, the FC process drying kinetics, no significant variations were observed between 80 and $90^{\circ} \mathrm{C}$, where the $X_{e}$ reached at 90 and $70^{\circ} \mathrm{C}$ were of 60 and $90 \mathrm{~min}$, respectively (Table 1). This process took less the least time to reach the $X_{e}$, it highlights the process with an input air temperature of $20^{\circ} \mathrm{C}$ and $1,120 \mathrm{~W}$ of microwave power. In this case, the equilibrium moisture content was reached in $10 \mathrm{~min}$ (see Table 1). Compared with the best results for jumbo squid samples treated only using FC (input air at $70^{\circ} \mathrm{C}$ ), the drying time was reduced $80 \mathrm{~min}$ (case $\mathrm{MWFC}-1,120$ and $20^{\circ} \mathrm{C}$ ). The microwaves $(1,120 \mathrm{~W})$ reducing drying time by eight times.

\section{Diffusivity and Modeling}

The values of the effective diffusivity coefficient obtained by Eq. (3), for different drying processes operating at different air temperatures, are presented in Table 1. As expected, effective diffusivity values rise with increasing drying air temperatures. It is worth mentioning that each drying method present diverse operational conditions as well as temperature vacuum and microwave. As for leaves drying experiments performed under natural convection, as expected, moisture diffusion rate should increase if drying process is conducted under forced-air convection. While vacuum drying, the temperature showed a smaller effect on the moisture diffusivity of leaves. This may be due to a higher porosity of the vacuum-dried samples provided by a large area-to-volume ratio (Jaya and Das, 2003), increasing the moisture diffusion rate associated to a higher vapor pressure gradient between the inside and outside of the sample being dried (Péré and Rodier, 2002). The different authors aforementioned showed high $D_{\text {eff }}$ values (Doymaz, 2006; Kaya, 2009), which could be a result of the use of different process settings (relative 


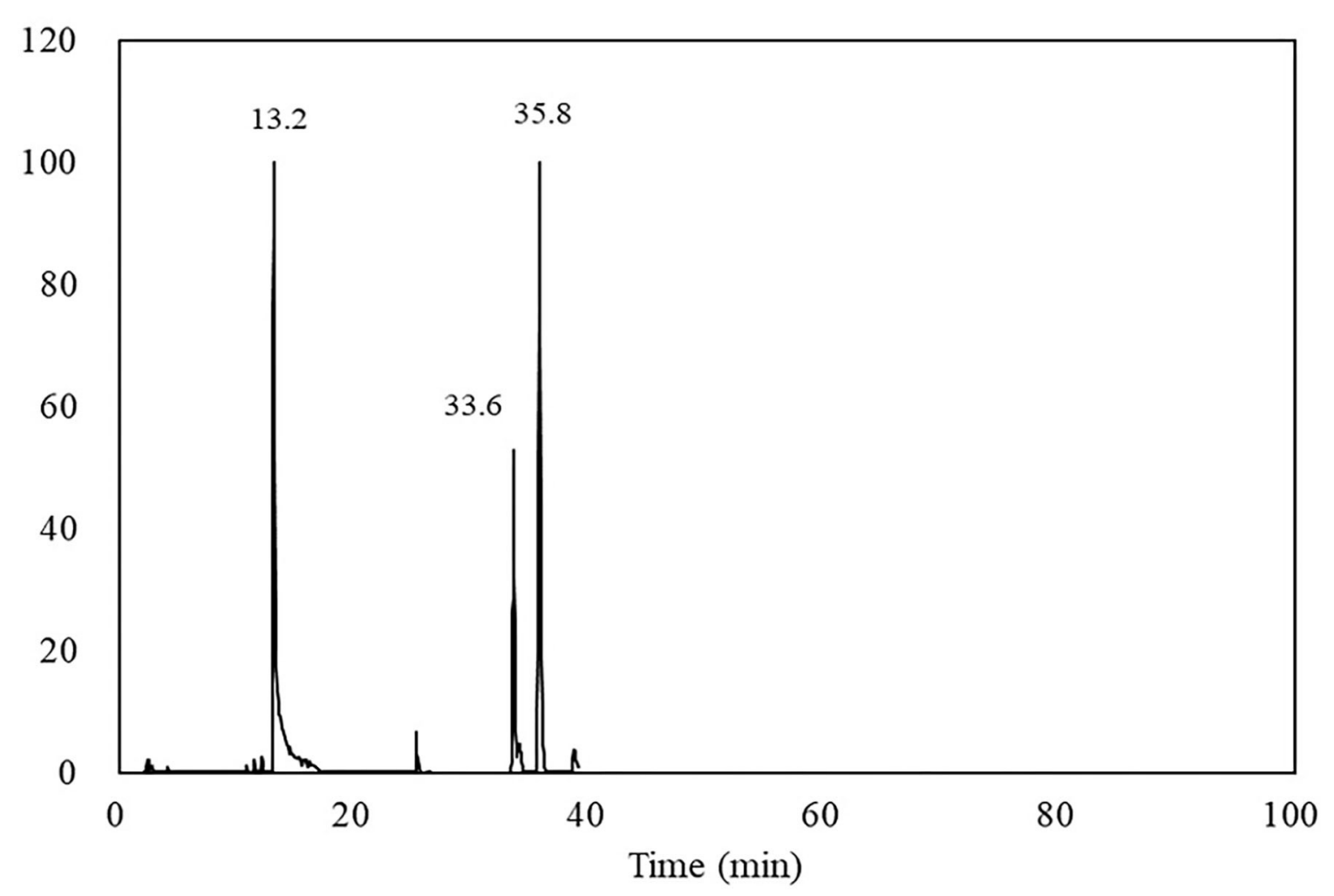

FIGURE 5 | Chromatographic profile of the phenolic compounds found in the dried Bollén leaves: Ursolic acid methylester $\left(\mathrm{C}_{31} \mathrm{H}_{50} \mathrm{O}_{3}\right)$ with Rt $=33.6$ and 35.8 min, and Prunasin $\left(\mathrm{C}_{14} \mathrm{H}_{17} \mathrm{NO}_{6}\right)$ with $\mathrm{Rt}=13.2 \mathrm{~min}$.

humidity, air-velocity, load-density, air-flow direction among others), as well as the leaves features under study (porosity, thickness and chemical composition). As for the $D_{\text {eff }}$ obtained values by Özbek and Dadali, these reflect that MWFC drying process achieved the highest values of $D_{\text {eff. It }}$ was noted that the greater the power of the microwave and the lower the air temperature, the coefficient $D_{\text {eff }}$ increases. In general, the highest $D_{\text {eff }}$ values are presented in the tests that had a drying shorter time what it could assume what it could also assume an energy saving. From the same Table 2, it was found that parameters $k$ and $\beta$ followed an increasing tendency as increasing temperature, which is a tendency similar to $D_{\text {eff }}$ behavior. In addition, the $n_{1}, n_{2}, c$, and $\alpha$ values remained relatively unchanged, suggesting them to be most probably dependent on the characteristics of the food (external skin, porosity, among others) and air properties (air-velocity, kind and/or direction of flow, etc.).

\section{Statistical Analysis of Models}

The analysis about RE\% values, this shows that it is not possible to generalize a model to a particular process and automatically expect a good performance. If the result does not represent a low RE\%, other models should be tested in each particular case. Also, diverse researchers have used the Midilli-Kucuk and Weibull models in drying kinetics of different herbs and leaves, which have gotten good results upon being applied, including
Doymaz (2006) in dill and parsley drying, Özbek and Dadali (2007) in mint drying, and Lemus-Mondaca et al. (2015) in Stevia leaves.

\section{Energy Consumption}

When NC drying was applied, the lowest energy consumption was obtained with an air temperature of $100^{\circ} \mathrm{C}$ and its value was $0.925 \mathrm{~kW} \cdot \mathrm{h}$. In the case of the VNC processes, they presented the highest energy consumption values, which exceeded $7.0 \mathrm{kWh}$. The FC process presents energy consumption under $1 \mathrm{~kW} \cdot \mathrm{h}$ in all the studied cases, and the best result $(0.664 \mathrm{~kW} \cdot \mathrm{h})$ is obtained with an air temperature of $80^{\circ} \mathrm{C}$. MWFC method presented the lowest energy consumption, because the time to reach the equilibrium moisture content are low (between 10 and $30 \mathrm{~min}$ ). It was found that the lowest energy consumption is obtained through MWFC drying with a power of $1,120 \mathrm{~W}$ and $20^{\circ} \mathrm{C}$ input air temperature. Thereby, the MWFC drying method has shown to be a promising drying technology, especially to decrease drying time as compared with drying methods under study. In addition, when the drying technologies are used combined, in this case, microwave and air-convective, for industrial-scale food drying, e.g., medicinal leaves with high biological potential, thus this drying method also could be regarded as a synergic technology, owing to reducing the processing time along with energy consumption. 


\section{Proximal, Polyphenols, and Interesting Compounds}

The MWFC drying process was only evaluated because this method showed the lowest energy consumption (shortest drying time) and leaves dried showed the best final appearance. As the leaves pass through the MWFC drying process, a significant decrease in moisture content in the dried leaves is observed. The values of lipids, ashes and crude fiber increase slightly while protein and carbohydrates values decrease. When compared with data obtained in a Stevia drying study, similar variations are observed Lemus-Mondaca et al. (2016). For example, in both leaf samples was a slight increase of ash and fat content, which is a common variation in the composition of natural food products (Lemus-Mondaca et al., 2016). This increasing polyphenol content of MWFC-dried leaves was mainly caused by decreasing moisture content. In addition, Das and Maulik (1994) showed that the antioxidant activity of $K$. oblonga leaves, they could have a probable relation with the antiinflammatory property.

The compounds represented by peaks tree were identified by comparison with commercial standard chromatographic characteristics. The compound corresponding to peak 1 [(M$\mathrm{H})^{-}$at $\mathrm{m} / \mathrm{z}$ 294.09], presenting a retaining time (Rt) of $13.2 \mathrm{~min}$., being identified as Prunasin $\left(\mathrm{C}_{14} \mathrm{H}_{17} \mathrm{NO}_{6}\right)$. Also, the compound represented by peaks two $\left[(\mathrm{M})^{+}\right.$at $\left.\mathrm{m} / \mathrm{z} 471.38\right]$ and three $\left[(\mathrm{M})^{+}\right.$at $\left.\mathrm{m} / \mathrm{z} 472.38\right]$ was identified as ursolic acid methylester $\left(\mathrm{C}_{31} \mathrm{H}_{50} \mathrm{O}_{3}\right)$, revealing two retaining time (Rt) of 33.6 and $35.8 \mathrm{~min}$. For $K$. oblonga leaves, ursolic acid, and prunasin have been isolated in earlier studies (Cassels and Ursúa, 1973; Fikenscher et al., 1981; Del Porte et al., 2002) only for fresh leaves. However, it is therefore important to note that during the microwave-drying process of $K$. oblonga leaves, these compounds are still remaining.

\section{CONCLUSIONS}

The energy consumption and quality of the dried K. oblonga leaf product have been studied by means of natural convection, natural vacuum convection, forced convection and microwaveassisted forced convection processes. In general, at lower temperatures the dry leaf tends to maintain its original green color, while drying time and energy consumption increase. The microwave-assisted forced convection (MWFC) process

\section{REFERENCES}

Amedorme, S. K., Apodi, J., and Agbezudor, K. (2013). Design and construction of forced convection indirect solar dryer for drying moringa leaves. Sch. J. Eng. Technol. 1, 91-97. doi: 10.36347/sjet

AOAC (1990). Association of Official Analytical Chemists. Official Method of Analysis no. 920.39, 962.09 and 934.06, 15th Edn. Arlington, VA: AOAV.

Avello-Lorca, M., Rivas-Fuentes, X., and Pastene-Navarrete, E. (2011). Evaluation of commonly used medicinal plants in concepcion city (Chile), through quality assays analytical. Bol. Latinoam y del Caribe Plantas Med. Aromat. 10, 379-388. Available online at: https://www.redalyc.org/articulo.oa?id=856/85619300011

Babu, A. K., Kumaresan, G., Raj, V. A. A., and Velraj, R. (2018). Review of leaf drying: mechanism and influencing parameters, drying methods, using a power and air inlet temperature of $1,120 \mathrm{~W}$ and $20^{\circ} \mathrm{C}$ respectively, showed the best performance in terms of energy consumption (3.73\%) and quality of the dried leaves. The microwave-assisted forced convection process enabled the equilibrium moisture values to be reached within $10 \mathrm{~min}$ of drying. Under these conditions the process had an effective diffusion coefficient of $16.72 \pm 2.3 \times 10^{-11} \mathrm{~m}^{2} / \mathrm{s}$. The proximal values show that the dry leaf is not altered by the MWFC drying process, neither did this process decrease the total polyphenols content; on the contrary, an increase was verified from 18.6 to $25.8 \mathrm{mg}$ GAE/g d.m. in the fresh until dried leaf, respectively. Thereby, this research shows it could be classed as a great previous for future and new investigations for bioactive compounds extraction and their possible uses pharmacological and healthy.

\section{DATA AVAILABILITY STATEMENT}

The original contributions presented in the study are included in the article/supplementary files, further inquiries can be directed to the corresponding author/s.

\section{AUTHOR CONTRIBUTIONS}

CZ designed the study, analyzed data, and revised the manuscript. $\mathrm{DH}$ conducted the experiments and wrote the manuscript draft. HR conducted the experiments and wrote part of the manuscript draft. NR conducted the experiments and analyzed data. RL-M participated in analysing results and revising the manuscript. All authors contributed to the article and approved the submitted version.

\section{FUNDING}

The work was supported by Departamento de Ciencia de los Alimentos y Tecnología Química Dirección de Investigación de la Facultad de Ciencias Químicas y Farmacéuticas, Universidad de Chile.

\section{ACKNOWLEDGMENTS}

The authors thank to the Fondo Nacional de Desarrollo Científico y Tecnológico CONICYT-FONDECYT 1161093. 
Doymaz, I. (2006). Thin-layer drying behaviour of mint leaves. J. Food Eng. 74, 370-375. doi: 10.1016/j.jfoodeng.2005.03.009

Feng, H., Yin, Y., and Tang, J. (2012). Microwave drying of food and agricultural materials: basics and heat and mass transfer modeling. Food Eng. Rev. 4, 89-106. doi: 10.1007/s12393-012-9048-x

Fikenscher, L., Hegnauer, R., and Ruijgrok, H. (1981). Distribution of hydrocyanic acid in cormophyta: 15.1 New observations on Cyanogenesis in Rosaceae. J. Med. Plant Res. 41, 313-327. doi: 10.1055/s-2007-971722

Hussein, I., Mamman, M., and Abdulrasheed, M. (2015). Effect of varying drying temperature on the antibacterial activity of Moringa oleifera leaf (Lam). IOSR J. Pharm. Biol. Sci. 10, 2319-7676. doi: 10.9790/3008-10453943

Jaya, S., and Das, H. (2003). A vacuum drying model for mango pulp. Drying Technol. 7, 1215-34. doi: 10.1081/DRT-120023177

Kaya, A. and Aydin, O. (2009). An experimental study on drying kinetics of some herbal leaves. Energ. Convers. Manage. 50, 118-124. doi: 10.1016/j.enconman.2008.08.024

Lemus-Mondaca, R., Ah-Hen, K., Vega-Gálvez, A., Homores, C., and Moraga, N. O. (2016). Stevia rebaudiana leaves: effect of drying process temperature on bioactive components, antioxidant capacity and natural sweeteners. Plant Foods Hum. Nutr. 71, 49-56. doi: 10.1007/s11130-015-0524-3

Lemus-Mondaca, R., Astudillo, S., Moraga, N., and Vega-Gálvez, A. (2015). Dehydration of Stevia rebaudiana Bertoni leaves: kinetics, modeling and energy features. J. Food Process. Preserv. 39, 508-520. doi: 10.1111/jfpp.12256

Menshutina, N. V., Gordienko, M. G., Voynovskiy, A. A., and Kudra, T. (2004). Dynamic analysis of drying energy consumption. Drying Technol. 22, 2281-2290. doi: 10.1081/DRT-200039996

Montenegro, G., Riveros, F., and Alcalde, C. (1980). Morphological structure and water balance of four Chilean shrub species. Flora 170, 554-564. doi: 10.1016/S0367-2530(17)31239-2

Montes, M., and Wilkomirsky, T. (1985). Medicina Tradicional Chilena. Editorial Universidad de Concepción, Concepción, Chile, p. 205.

Motevali, A., Minaei, S., and Khoshtagaza, M. H. (2011). Evaluation of energy consumption in different drying methods. Energy Convers. Manage. 52, 1192-1199. doi: 10.1016/j.enconman.2010.09.014

Özbek, B., and Dadali, G. (2007). Thin-layer drying characteristics and modelling of mint leaves undergoing microwave treatment. J. Food Eng. 83, 541-549. doi: 10.1016/j.jfoodeng.2007.04.004

Panchariya, P. C., Popovic, D., and Sharma, A. L. (2002). Thin-layer modelling of black tea drying process. J. Food Eng. 52, 349-357. doi: $10.1016 / \mathrm{S} 0260-8774(01) 00126-1$

Park, J. K., Vohnikova, Z., and Reis-Brod, P. F. (2002). Evaluation of drying parameters and desorption isotherms of garden mint leaves (Mentha crispa L.). J. Food Eng. 51, 193-199. doi: 10.1016/S0260-8774(01) 00055-3
Péré, C., and Rodier, E. (2002). Microwave vacuum drying of porous media: experimental study and qualitative considerations of internal transfers. Chem. Eng. Process. 41, 427-436. doi: 10.1016/S0255-2701(01)00161-1

Pinela, J., Barros, L., Carvalho, A., and Ferreira, I. (2011). Influence of the drying method in the antioxidant potential and chemical composition of four shrubby flowering plants from the tribe Genisteae (Fabaceae). Food. Chem. Toxicol. 49, 2983-2989. doi: 10.1016/j.fct.2011.07.054

Recio, M. R., Giner, R. M., Máñez, S., Gueho, J., Julien, H. R., Hostettmann, K., et al. (1995). Investigations on the steroidal anti-inflammatory activity of triterpenoids from Diospyros leucomelas. Planta Med. 61, 9-12. doi: 10.1055/s-2006-957988

Rodríguez, R., Ruiz, E., and Elissetche, J. P. (2006). Arboles Nativos de Chile, 1st Edn. Editorial Universidad de Concepción (ISBN 956-227-290-7), Concepción, Chile, pp. 183.

Russo, A., and Garbarino, J. (2008). Solidago chilensis Meyen and Kageneckia oblonga Ruiz and Pav: a minireview on their antioxidant profile. Phytotherapie 6, 333-341. doi: 10.1007/s10298-008-0345-8

Talhaoui, N., Vezza, T., and Gómez-Caravaca, A. M. (2016). Phenolic compounds and in vitro immunomodulatory properties of three Andalusian olive leaf extracts. J. Funct. Food 22, 270-277. doi: 10.1016/j.jff.2016.01.037

Taralkar, S. V., and Chattopadhyay, S. (2012). A HPLC method for determination of ursolic acid and betulinic acids from their methanolic extracts of vitex negundo Linn. J. Anal. Bioanal. Tech. 3:134. doi: 10.4172/2155-9872.1000134

Togrul, I. T., and Pehlivan, D. (2003). Modelling of drying kinetics of single apricot. J. Food Eng. 58, 23-32. doi: 10.1016/S0260-8774(02)00329-1

Vadivambal, R., and Jayas, D. S. (2007). Changes in quality of microwavetreated agricultural products-a review. Biosys. Eng. 98, 1-16. doi: 10.1016/j.biosystemseng.2007.06.006

Vega-Gálvez, A., Puente-Díaz, L., Lems-Mondaca, R., Miranda, M., and Torres, M. J. (2014). Mathematical modeling of thin-layer drying kinetics of cape gooseberry (Physalis peruviana L.). J. Food Process. Preserv. 38, 728-736. doi: $10.1111 /$ jfpp. 12024

Conflict of Interest: The authors declare that the research was conducted in the absence of any commercial or financial relationships that could be construed as a potential conflict of interest.

Copyright (๑) 2021 Zambra, Hernández, Reyes, Riveros and Lemus-Mondaca. This is an open-access article distributed under the terms of the Creative Commons Attribution License (CC BY). The use, distribution or reproduction in other forums is permitted, provided the original author(s) and the copyright owner(s) are credited and that the original publication in this journal is cited, in accordance with accepted academic practice. No use, distribution or reproduction is permitted which does not comply with these terms. 